\title{
KITAB KUNING SEBAGAI LITERATUR KEISLAMAN DALAM KONTEKS PERPUSTAKAAN PESANTREN
}

\author{
Mustofa \\ Pustakawan Ahli Muda ISI Surakarta \\ Email: mmustofa81@gmail.com
}

\begin{abstract}
ABSTRAK
Kitab Kuning Sebagai Literatur Keislaman Dalam Konteks Pesantren. Metode yang digunakan dalam penulisan artikel ini adalah studi literatur. Kitab kuning menjadi salah satu sistem nilai dalam kehidupan pesantren. Karena itu, pembelajaran dan pengkajian kitab kuning menjadi nomor satu dan merupakan ciri khas pondok pesantren. Kitab kuning menjadi sesuatu yang substansial sebagai rujukan. Kitab Kuning merupakan literatur keislaman di lembaga pendidikan Islam khususnya pesantren. Metode yang digunakan dalam pengajaran Kitab Kuning yaitu dengan sorogan dan bandongan. Kritik terhadap kitab kuning perlu dilakukan agar pemahaman terhadap konteks kekinian atau kesesuiain masalah terhadap zamannya bisa diterapkan.
\end{abstract}

Kata Kunci : Kitab Kuning, Literatur Keislaman, Pesantren

\section{PENDAHULUAN}

Pesantren merupakan lembaga pendidikan tradisional Islam yang bisa survive sampai hari ini. Dalam pandangan Azra (1999:95), hal ini berbeda dengan lembaga pendidikan tradisional Islam di kawasan dunia muslim lainnya, dimana akibat gelombang pembaharuan dan modernisasi yang semakin kencang, telah menimbulkan perubahan-perubahan tradisional.

Majid mengatakan (1997:5) "dalam tinjauan kelembagaan pendidikan, pesantren mempunyai sesuatu yang unikunik". Keunikan dan kekhasan pesantren menarik sejumlah pakan dan tokoh "alumni" pesantren untuk terus membahas dan mengkaji secara mendalam sisi-sisi kekhasanny, Bruisen (1995). Sebagai lembaga pendidikan berbasis agama (educational institution-based religion), pesantren pada mulanya merupakan pusat penggemblengan nilai-nilai dan penyebaran agama Islam. Namun dalam perkembangannya, lembaga ini semakin memperlebar wilayah garapannya yang tidak hanya mengakselerasikan mobilitas vertikal, tetapi juga mobilitas horisontal, Sanusi (2013:61).

Karena watak utamanya adalah lembaga pendidikan Islam, maka pesantren dengan sendirinya memiliki tradisi keilmuan tersendiri. Tradisi ini mengalami perkembangan dari masa ke masa dan 
menampilkan manifestasi yang berubahubah dari waktu ke waktu. Walau demikian, masih dapat ditelusuri beberapa hal inti yang tetap merupakan tradisi keilmuan pesantren, sejak datangnya Islam ke Indonesia hingga saat ini. Kesemuanya itu menunjuk ke sebuah asal-usul yang bersifat historis sekaligus merupakan pendorong utama bagi berkembangnya pesantren itu sendiri, Siswanto (2006:9).

Kitab kuning menjadi salah satu sistem nilai dalam kehidupan pesantren. Karena itu, pembelajaran dan pengkajian kitab kuning menjadi nomor satu dan merupakan ciri khas pondok pesantren. Kitab kuning menjadi sesuatu yang substansial sebagai rujukan. Oleh karena itu, perkembangan pondok pesantren yang semakin dinamis dan mengikuti perkembangan pendidikan secara nasional, pondok pesantren tetap mempertahankan kitab kuning sebagai bahan pembelajaran baik pada pesantren salafiyah maupun kholafiyah. Ketetapan pada kitab kuning ini menjadikan pondok pesantren memiliki kekhasan tersendiri, hal ini ditambah dengan 2 penekanan kitab kuning yang dipelajari oleh pesantren, seperti kajian fiqih, kajian aqidah, kajian tafsir, dan kajian tasawuf. Dan untuk mengetahui keberhasilan atau tercapainya tujuan dalam program pembelajaran kitab kuning tersebut salah satu cara yang dapat ditempuh ialah dengan melaksanakan penilaian atau evaluasi.

Dari latar belakang masalah di atas yang menjadi rumusan masalahnya yaitu Bagaimana Kitab Kuning Menjadi Literatur Keislaman Dalam Konteks Perpustakaan Pesantren?

\section{PEMBAHASAN}

\section{a. Pengertian Kitab Kuning}

Kitab klasik yang lebih dikenal dengan nama kitab kuning mempunyai peranan yang sangat penting dalam mengembangkan ajaran agama Islam. Menurut Azyumardi Azra, (2002 : 111) "Kitab Kuning mempunyai format sendiri yang khas dan warna kertas "kekuning-kuningan".1 Melihat dari warna kitab ini yang unik maka kitab ini lebih dikenal dengan kitab kuning. Akan tetapi akhirakhir ini ciri-ciri tersebut telah mengalami perubahan. Kitab kuning cetakan baru sudah banyak memakai kertas putih yang umum dipakai di dunia percetakan. Juga sudah banyak yang tidak "gundul" lagi karena telah diberi syakl untuk memudahkan santri membacanya. Sebagian besar kitab kuning sudah dijilid. 
Imam Bawani (1990:134) menyatakan bahwa kitab kuning dikenal juga dengan kitab gundul karena memang tidak memiliki harakat (fathah, kasrah, dhammah, sukun), tidak seperti kitab alQuran pada umumnya. Oleh sebab itu, untuk bisa membaca kitab kuning berikut arti harfiah kalimat per kalimat agar bisa dipahami secara menyeluruh, dibutuhkan waktu belajar yang relatif lama. Istilah kitab kuning sebenarnya diletakkan pada kitab warisan abad pertengahan Islam yang masih digunakan pesantren hingga saat ini.

Dari pengertian di atas bisa disimpulkan bahwa kitab kuning adalah kitab literatur dan referensi Islam dalam bahasa Arab klasik meliputi berbagai bidang studi Islam seperti Quran, Tafsir, Ilmu Tafsir, Hadits, Ilmu Hadits, Fiqih, Ushul Fiqih, Aqidah Fiqih, Tauhid, Ilmu Kalam, Nahwu dan Sharaf atau ilmu lughah termasuk Ma'ani Bayan Badi' dan Ilmu Mantik, Tarikh atau sejarah Islam, Tasawuf, Tarekat, dan Akhlak, dan ilmuilmu apapun yang ditulis dalam Bahasa Arab tanpa harokat, mempunyai format sendiri yang khas dan warna kertas "kekuning-kuningan", yang biasanya dipelajari terutama di pesantren.

\section{b. Pengertian Perpustakaan}

Pesantren

Menurut Djamaluddin

(1998:99) pondok pesantren adalah suatu lembaga pendidikan agama Islam yang tumbuh serta diakui oleh masyarakat sekitar, dengan sistem asrama (kampus) yang santri-santrinya menerima pendidikan agama melalui sistem pengajian atau madrasah yang sepenuhnya berada di bawah kedaulatan dan kepemimpinan seorang atau beberapa orang kyai dengan ciri-ciri khas yang bersifat kharismatis serta independen dalam segala hal.

Basuki dalam Aulia

(2008:11) mendifinisikan bahwa perpustakaan pesantren adalah perpustakaan yang terdapat di pesantren atau pondok yang digunakan untuk siswa pesantren dan (kadang-kadang) lingkungan sekitarnya. Definisi ini tidak signifikan karena tidak membedakan pesantrean dan sekolah. Maka sebetulnya tidak ada definisi yang baku tentang perpustakaan pesantren. Dan karena pada dasarnya perpustakaan pesantren adalah perpustakaan sekolah, maka definisi atau batasan yang digunakan di sini untuk mendefinisikan perpustakaan pesantren adalah definisi perpustakaan sekolah.

Di Indonesia pondok pesantren lebih dikenal dengan istilah Kutab merupakan suatu lembaga pendidikan 
Islam, yang di dalamnya terdapat seorang kyai (pendidik) yang mengajar dan mendidik para santri (anak didik) dengan sarana masjid yang digunakan untuk menyelenggarakan pendidikan tersebut, serta didukung adanya pondok sebagai tempat tinggal para santri, Hasbullah (1996:24).

\section{c. Elemen Pondok Pesantren}

Dhofier

(1994:44)

mengungkapkan bahwa lembaga pendidikan pesantren memiliki beberapa elemen dasar yang merupakan ciri khas dari pesantren itu sendiri, elemen itu adalah:

1) Pondok atau Asrama

Dalam tradisi pesantren, pondok merupakan unsur penting yang harus ada dalam pesantren. Pondok merupakan asrama di mana para santri tinggal bersama dan belajar di bawah bimbingan kiai. Pada umumnya pondok ini berupa komplek yang dikelilingi oleh pagar sebagai pembatas yang memisahkan dengan lingkungan masyarakat sekitarnya. Namun ada pula yang tidak terbatas bahkan kadang berbaur dengan lingkungan masyarakat.

2) Masjid

Masjid merupakan elemen yang tidak dapat dipisahkan dengan pesantren, masjid adalah bangunan sentral sebuah pesantren, dibanding bangunan lain, masjidlah tempat serbaguna yang selalu ramai atau paling banyak menjadi pusat kegiatan pesantren. Masjid yang mempunyai fungsi utama untuk tempat melaksanakan sholat berjamaah, melakukan wirid dando "a, ietikaf dan tadarus AlQuran atau yang sejenisnya.

\section{3) Santri}

Istilah "santri" mempunyai dua konotasi atau pengertian, pertama; dikonotasikan dengan orang-orang yang taat menjalankan dan melaksanakan perintah agama Islam, atau dalam terminologi lain sering disebut sebagai "muslim orotodoks".Istilah "santri" dibedakan secara kontras dengan kelompok abangan, yakni orangorang yang lebih dipengaruhi oleh nilai-nilai budaya jawa pra Islam, khususnya nilai-nilai yang berasal dari mistisisme Hindu dan Budha. Kedua; dikonotasikan dengan orang-orang yang tengah menuntut ilmu di lembaga pendidikan pesantren. Keduanya jelas berbeda, tetapi jelas pula kesamaannya, yakni sama-sama taat dalam menjalankan syariat Islam. 
4) Pengajaran Kitab-Kitab Agama

Salah satu ciri khusus yang membedakan pesantren dengan lembaga-lembaga pendidikan yang lain adalah adanyapengajaran kitab-kitab agama klasik yang berbahasa Arab, atau yang lebih populer disebut dengan kitab kuning

5) Kiai atau Ustadz

Keberadaan kiai dalam lingkungan pesantren merupakan elemen yang cukup esensial. Laksana jantung bagi kehidupan manusia begitu urgen dan pentingnya kedudukan kiai, karena dialah yang merintis, mendirikan, mengelola, mengasuh, memimpin dan terkadang pula sebagai pemilik tunggal dari sebuah pesantren. Oleh karena itu, pertumbuhan suatu pesantren sangat bergantung kepada kemampuan pribadi kiainya, sehingga menjadi wajar bila melihat adanya banyak pesantren yang bubar, lantaran ditinggal wafat kiainya, sementara dia tidak memiliki keturunan yang dapat meneruskan kepemimpinannya.

6) Cara Pengajaran Kitab Kuning Menurut Alphandi (1984:71) dalam pesantren, ada beberapa metode yang biasa digunakan oleh kyai atau ustadz dalam melakukan pengajaran kitan kuning dengan arab pegon. Pengajaran kitab kuning terbagi dalam 2 jenis, yaitu : pertama secara individual atau biasa disebut dengan sistem sorogan, kedua secara berkelompok atau disebut dengan bandongan.

Selain kedua metode tersebut, sejalan dengan usaha kontekstualisasi kajian kitab kuning, di lingkungan pesantren dewasa ini telah berkembang metode jalsah "diskusi kelompok" dan halaqoh "seminar" Pada awalnya metode ini lebih sering digunakan pada tingkat kyai - ulama atau pengasuh pesantren, namun pada masa sekarang sudah biasa dilakukan oleh santri. Biasanya untuk membahas isuisu kontemporer dengan bahanbahan pemikiran yang bersumber dari kitab kuning.

a) Metode Sorogan

$$
\begin{aligned}
& \text { Sistem individual dalam } \\
& \text { sistem pendidikan Islam } \\
& \text { tradisonal disebut dengan sistem } \\
& \text { sorogan yang diberikan dalam }
\end{aligned}
$$


pengajian kepada murid-murid yang telah menguasai pembacaan Qur'an. Santri membacakan kitab kuning dihadapan kyai-ulama yang langsung menyaksikan keabsahan bacaan santri baik dalam konteks makna maupun bahasa (nahw dan Shorf). Sorogan artinya belajar secara individu dimana seorang santri berhadapan dengan seorang guru terjadi interaksi saling mengenal diantara keduanya, Matushu (1994:6).

b) Metode Bandongan

Winarmo mengatakan (1979:85) bahwa metode utama sistem pengajaran di lingkungan pesantren yaitu sistem bandongan atau seringkali disebut sistem weton. Secara etimologi dalam kamus besar bahasa Indoensia, bandongan diartikan dengan pengajaran dalam bentuk kelas (pada seklek agama). Dalam sistem ini sekelompok murid (antara 5 sampai 500) mendengarkan seorang guru yang membaca, menerjemahkan, menerangkan dan seringkali mengulas bukubuku Islam dalam bahasa Arab.
Setiap murid memperhatikan bukunya sendiri dan membuat catatan tentang kata-kata atau buah pikiran yang sulit berupa sakal atau makna mufrodat atau penjelasan keterangan tambahan. Kelompok kelas dari sistem bandongan ini disebut halaqoh yang arti bahasanya lingkaran murid atau sekelompok siswa yang belajar dibawah bimbingan seorang guru.

7) Kitab Kuning dan Pendidikan di Pesantren

Menurut Susanti (2015) pendidikan pesantren dapat menjadi pendidikan unggul baik keilmuan maupun mentalitas dan moralitas santri. Karena di pesantren santrinya belajar mulai ba'da shubuh hingga jam sebelas malam, artinya mereka belajar paling tidak selama 16 jam. Sangat logis santri pesantren banyak ilmunya.Begitu pula mereka unggul dalam moralitas karena mereka senantiasa diberikan pelajaran ntuk berperilaku yang baik, baik didalam kelas maupun diluar kelas, contoh - contoh perilaku baik itu langsung diberikan oleh kyai atau ustadz 
pengganti kyai.

Di pesantren, santri belajar membaca Al-Qur'an dengan tajwidnya. Juga mengkaji ilmu agama melalui guru atau kyai dan mereka memiliki rujukan melalui kitab kuning. Mulanya mereka belajar masalah aqidah, ibadah \& muamalah kemudian ditambah dengan pelajaran - pelajaran seperti mantiq, balaghah, faraidl dan bidang lainnya. Belajar kitab kuning dalam pesantren ini melalui tingkatan - tingkatannya, mulai tingkat awal kemudian sampai tingkat lanjutan sesuai dengan keberadaan lamanya mereka belajar di pondok itu.

Dari dinamikanya, pesantren dapat dikelompokan menjadi tiga tipe yaitu pesantren salafiyah yaitu pesantren yang memfokuskan dirinya belajar agama melalui kitab kuning. Ada pula pesantren disamping belajar kitab kuning tetapi siswanya belajar ilmu umum di sekolah formal seperti SLTP / SMU atau madrasah yang disebut dengan pesantren kombinasi. Ada pula pesantren yang hanya menekankan santrinya belajar ilmu agama dan umum adapun kitab kuning tidak dibebankan kepada santri yang disebut pesantren khalafiyah atau 'Asyriyah.

8) Kitab kuning yang diajarkan di Pesantren

Menurut Husein (2015), kajian dalam Kitab Kuning meliputi berbagai cabang keilmuan Islam yang -menurut imam as-Suyûthî (w. $911 \mathrm{H}$ )- berjumlah empat belas cabang ilmu dan pengetahuan. Akan tetapi, sepanjang diketahui secara populer di pesantren, dari jumlah itu, hanya ada beberapa saja yang diajarkan, yakni : fiqih (fiqh), akidah ('aqîdah), tata-bahasa Arab (al-qawâ'id al-'Arâbiyyah) -yang meliputi nahwu (nahw), Sharaf (sharf), dan balaghah- hadis (hadîst), tasawuf (tashawwuf), dan sejarah nabi (as-sirâh annabawiyah) hingga periode empat khalifah sesudah Nabi (al-khulafâ' ar-râsyidûn). Di samping itu, diajarkan juga ilmu-ilmu pengetahuan lainya, yakni; tafsir al-Quran (tafsîr), teologi (ilm alkalâm), usul fiqih (ushûl al fiqh), logika (manthiq), sejarah peradapan Islam hingga dunia Islam kontemporer (hadhir al-'âlam al islâmî). Berbagai pengantar keilmuan mendapatkan perhatian yang sangat kecil dan bahkan ada 
yang tidak diajarkan sama sekali, seperti filsafat.

Diantara Kitab Kuning yang diajarkan secara intensif itu ternyata, ada banyak sesungguhnya yang berasal dari satu "gen". "Gen" atau matan (matn) ini kemudian dikembangkan menjadi komentar (syarh), catatan pinggir (hâsyiah), bahkan ada kalanya muncul dalam bentuk ringkasan (mukhtashar) dan syair (nadzâm). Demikianlah, Kitab Kuning dalam pesantren berjalan dalam siklus yang tetap: mengembang-menyempit, berputar dan berulang. Beberapa contoh untuk ini dapat dikemukakan, misalnya, dalam fiqh: at-Taqrîb, Fath alQarîb, karya Al-Bâjûri, Qurrah al-'Ayn, Fath al-Mu'in, I'ânah ath-Thâlibîn atau Nihayah az-Zayn. Contoh dalam bidang nahwu adalah; al-Ajurumiah, al'asymawi, ad-dahlan, al-karawi, almutammimah,al-'imrithî hingga alfiyyah ibn Malik dan Ibn aqil. Sebuah cabang ilmu boleh jadi dikupas dan diringkas dalan puluhan Kitab Kuning. Semuanya diajarkan berulang-ulang dan bertahun-tahun selama mengikuti pendidikan di pesantren.
Selanjutnya, kita juga dapat melihat bahwa Kitab Kuning yang diajarkan di pesantren lebih menitik beratkan aspek pendalaman dan pengayaan materi dan sangat sedikit diarahkan pada aspek pengembangan teori, metodologi, dan wawasan. Padahal, semua yang disebut terakhir ini sesungguhnya justru menjadi unsur-unsur keilmuan yang mendasar.

Dari sini, barang kali, orang dapat mengatakan bahwa masyarakat pesantren memang lebih kaya materi, tetapi miskin teori metodologi. Ini berbeda halnya dari masyarakat "sekolahan". Maka, tidaklah mengherankan lagi bahwa, ketika aspek teori dan metodologi terabaikan, kekayaan materi menjadi sulit dikembangkan dan diekspreskan secara kontekstual dan mengesankan atau, apalagi, berambisi melakukan pembaruan pemikiran Islam. Yang lebih penting lagi adalah bahwa kekayaan materi yang dimiliki pesantren lebih terpusat pada kajian fiqih sebagai produk pemikiran saja dan bukan dipandang sebagai proses pemikiran dinamis yang tengah merespon perkembangan di 
zamannya. Dalam kajian fiqih ini, kapitasnya lebih menyempit lagi, yakni dalam bidang (bab) ibadah saja. Bab-bab lainnya seperti mu'âmalah, jinâyah, murâfa'ah, dan al 'alaqah ad-dawliyyah kurang serius dipelajari.

9) Kontekstualisasi Kitab Kuning

Husein menyatakan (2015) bahwa di hadapan perubahanperubahan sosial yang semakin gencar dan dahsyat dewasa ini, pesantren dalam perkembangan paling akhir masih setia memandang Kitab Kuning sebagai khazanah intelektual dan referensi keagamaan yang paling absah dan sakral. Konsekuensi cara pandang ini adalah bahwa kritik-kritik atau "gugatan-gugatan" terhadap Kitab Kuning, baik secara metodologis maupun secara substansi, isi, dianggap tidak etis, tidak sopan sekaligus memunculkan stigma. Tetapi, di sisi lain, disadari atau tidak, gempuran-gempuran modernisme secara sistematis dan berjalan cepat, sesungguhnya telah mengubah cara pandang masyarakat dari sakralisasi tradisi menuju profinasi, dari hal-hal yang bersifat keakhiratan ke hal-hal yang bersifat keduniaan dan dari cara pandang tradisional ke cara pandang rasional. Ketika Kitab Kuning diyakini sebagi sumber dan acuan paling baku untuk bisa menjawab berbagai persoalan kehidupan kapan dan dimanapun, dalam waktu yang sama Kitab Kuning ditantang oleh kecenderungan realitas sosial baru yang selalu berubah dan berwatak pluralistrik.

Maka tidaklah mengherankan ketika pemikiran-pemikiran baru sebagai tuntutan modernitas itu muncul dengan meminta jawaban yang relevan. Kitab Kuning lalu seolah-olah tidak diperhitungkan sebagai sumber jawaban yang efektif, bahkan disadari atau tidak ditinggalkan oleh pemeluknya sendiri. Kitab Kuning menjadi kehilangan daya tariknya justeru oleh sebagian produk pesantren sendiri. Adalah sikap apologia belaka jika semua persoalan social kemasyarkatan telah termaktub jawabannya dalam Kitab Kuning. Kenyataan sosial menunjukkan bahwa keyakinan apologis itu masih membutuhkan kajian yang intens (ijtihâd) untuk mengkontekstualisasikannya.

Kemudian, manakala hal ini 
dipandang riskan untuk dilakukan, maka jawaban yang muncul adalah mendiamkannya (tawaqquf). Dengan demikian, stagnasi pemikiran menjadi tak terelakan. Sementara itu, pemecahan atas kebuntuan semacam ini hanya bisa diterobos melalui pendekatan nonkitab Kuning. Bila pun KK menyediakan jawaban tekstualnya, tetapi apakah ia bisa memberi jalan keluar yang efektif dan masalahat?. Apa boleh buat, tradisi menyelesaikan masalah melalui Kitab Kuning akhirnya tergugat dengan sendirinya.

Adalah sangat mengesankan dan sekaligus menimbulkan optimisme baru di kalangan pesantren bahwa, pada bulan Desember 1988, untuk pertama kalinya digelar sebuah Munâzharah antar kiai-ulama di Pesantren Watucongol, Muntilan. Munâzharah -selanjutnya halaqahitu secara esensial dimaksudkan sebagai upaya menerobos kebuntuan pemikiran melalui pendekatan kontekstualisasi Kitab Kuning.

Kajian ini mencoba mengulang kembali atau menegaskan komitmen para penganut Kitab
Kuning untuk tetap setia pada Kitab Kuning tanpa mengabaikan tuntutan-tuntutan modernitas. Tulisan ini juga memaparkan ihwal bagaimana sesungguhnya Kitab Kuning harus dipahami dan apa yang patut diberikan ketika mengajarkan Kitab Kuning agar tetap relevan dengan kebutuhan kekinian.

10) Kitab Kuning Masih Relevan Untuk Dipelajarari

Menurut Haedari (2008) kitab kuning berisi hasil pemikiran ulama di masa lampau dalam berbagai bidang. Paling banyak adalah bidang fikih. Selain itu, juga bidang akidah, akhlak, tasawuf, tafsir, dan hadis. Sebagian kecil lagi membahas ilmu kalam (teologi) dan filsafat. Benarkah kitab kuning sudah tidak relevan dan ketinggalan zaman? "Kitab kuning sampai saat ini masih cukup relevan karena itu bisa dikembangkan," Berikut ini penjelaskan tentang kitab kuning dan relevansinya di masa sekarang ini.

Kitab kuning hanya istilah saja tapi yang jelas artinya adalah kitabkitab yang berbahasa Arab dan ada juga yang termasuk kitab-kitab 
yang termasuk modern seperti AlMaraghi. Kitab kuning adalah sebuah kitab tafsir. Sebetulnya dari kitab-kitab klasik tersebut bisa diangkat untuk hal-hal yang modern juga. Yang terpenting, adalah bagaimana para santri itu memahami tak hanya yang tekstual saja, tetapi juga yang kontekstual. Jadi, di dalam membaca kitab itu tidak hanya bersifat tekstual tetapi juga bagaimana analisis mereka terhadap teks itu. Kitab kuning sampai saat ini masih cukup relevan karena teori-teorinya bisa dikembangkan.

Spirit yang bisa diambil dari mempelajari kitab kuning : Kalau kita mengkaji kitab kuning, kita melihat bagaimana semangat belajar para ulama terdahulu. Semangat keilmuan mereka cukup tinggi. Karena itu, para santri dan ustadz harus kembali kepada tradisi intelektual pesantren yang bersumber kepada kitab-kitab kuning. Dulu kita mengenal ulama asal Banten $\mathrm{KH}$ Nawawi Al Banteni yang kitabnya berbahasa Arab menjadi rujukan umat Islam tak hanya di Indonesia tetapi juga di Timur Tengah. Apakah kegiatan semacam musabaqah beberapa waktu lalu diarahkan ke sana?

Betul. Ulama-ulama Indonesia yang sekelas Nawawi Al Bantani, Syekh Yasin Padang, dan lainnya buku-bukunya menjadi referensi di Timur Tengah. Begitu juga Mahfud at-Tarmidzi, Abdurrauf Singkel, dan banyak sekali ulama-ulama Indonesia yang go internasional di masa lampau. Nanti, para santri ini kami dorong supaya juga menulis dan menulis sehingga tahun ini kami akan mencoba menggerakkan dari karya-karya santri itu untuk mendorong menulis. Kalau tulisannya bagus kita siap untuk menerbitkannya. Sehingga nanti akan tumbuh budaya menulis, semangat untuk menulis. Saya kira sangat jarang sekali sekarang yang menulis di bidang ilmu sharaf, fikih sudah ada tapi perlu difasilitasi supaya nanti menjadi besar.

11) Kritik Terhadap Kitab Kuning Kitab kuning selama ini dikenal sebagai literatur (maraji' atau ma'khad) wajib bagi santri di pesantren-pesantren tradisional di seluruh pelosok tanah air. Dengan membaca kitab kuning kalangan pesantren mencoba bersikap, memaknai dan menjawab 'hampir' 
seluruh persoalan yang muncul dan berkembang. Persoalan muncul kemudian, setelah ada dua kategori kitab kuning. Kitab mu'tabarah (valid untuk di ruju') dan kitab gair mu'tabarah (tidak valid di ruju') sebagian besar pesantren tradisional menggunakan pakem keagamaan yang sama, yaitu nada keberagaman dalam pakem kitab kuning yang mu'tabarah.

Lalu pembacaan tafsir-tafsir ajaran agama dalam berbagai disiplinnya, yang tadinya menghargai berbagai pandangan yang berbeda, kemudian hanya menghargai dan akrab dengan ajaran-ajaran versi kitab mu'tabarah. Bila ada kyai atau pesantren yang keluar dari pakem ini, habislah sudah otoritasnya.

Pembatasan rujukan hanya pada kitab-kitab mu'tabarah sejatinya lebih cenderung sebagai upaya ideologisasi, dan tidak murni kerja-kerja ilmiah. Karena itu kecenderungan demikian sungguh layak dicurigai kecenderungan yang tidak kondusif bagi pengembangan keilmuwan pesantren tersebut. Realitas diperparah oleh penuhanan metode pembacaan dan kajian keagamaan.
Yakni penuhanan pada metode ambil comot teks alias tekstualis, dan juga metode gampang percaya pada konon konon kata ulama' alias taqlid qaulan.

Akibatnya kitab kuning dibaca dan didekati sebagai korpus tertutup, yang ahistoris, dan anti kritik. Pembacaan dan pemahaman yang dilakukan pun cenderung berulang-ulang. Masalah apa pun muncul, segera dicarikan jawabannya dari kitab kuning mu'tabarah begitu saja, tanpa membandingkan perbedaan konteks zamaninya, padahal kitabkitab itu berisi pandangan ulama yang ditawarkan untuk menyelesaikan persoalan pada zaman dan tempat yang jauh berbeda dengan konteks kekinian dan kedisinian.

\section{PENUTUP}

Dari uraian di atas bisa disimpulkan bahwa Kitab Kuning merupakan literatur keislaman di lembaga pendidikan Islam khususnya pesantren. Metode yang digunakan dalam pengajaran Kitab Kuning yaitu dengan sorogan dan bandongan. Ciri utama penggunaan sistem individual atau sorogan ini adalah : 1) Lebih mengutakaman proses belajar daripada 
mengajar. 2) Merumuskan tujuan yang jelas. 3) Mengusahakan partisipasi aktif dari pihak murid 4) menggunakan banyak feedback atau balikan dan evaluasi. 5) Memberi kesempatan kepada murid untuk maju dengan kecepatan masing-masing.

Pola pemikiran pertama dimaksudkan sebagai cara dan kecenderungan dalam mengkaji dan menyelesaikan suatu persoalan dengan lebih memperhatikan aspek lahiriyah dan riwayat dari semua teks. Dasar perpektif ini adalah : "al-Isnad min al-Din". Sanad/transmisi adalah bagian dari agama). Jadi nara sumber berita menjadi prinsip penting untuk menilai benar atau tidak, sah atau tidaknya sebuah berita merupakan bagian dari agama.

Kritik terhadap kitab kuning perlu dilakukan agar pemahaman terhadap konteks kekinian atau kesesuiain masalah terhadap zamannya bisa diterapkan. Tentunya permasalah yang ada pada saat ini berbeda dengan masalah yang terjadi jaman dulu. Jangan sampai masalah apa pun yang muncul, hanya dicarikan jawabannya dari kitab kuning mu'tabarah begitu saja, tanpa membandingkan perbedaan konteks zamaninya, walaupun kitab-kitab itu berisi pandangan ulama yang ditawarkan untuk menyelesaikan persoalan pada zaman dan tempat yang jauh berbeda dengan konteks kekinian. 4 .

\section{DAFTAR PUSTAKA}

Ahmad Haedari, Kitab Kuning Masih Relevan Dipelajari dlm http://khazanah.republika.co.id/berit a/dunia-islam/islamnusantara/08/12/23/22166-aminhaedari-ma-kitab-kuning-masihrelevan-dipelajari diakses pada tanggal 2 Desember.

Aulia Agus Iswar, Manajemen Perpustakaan Pesantren, dalam http://lib.ui.ac.id/file?file=digital/126 764-RB13I403mManajemen\%20perpustakaanLiteratur.pdf diakses pada tanggal 5 Desember 2018.

Azumardi Azra, Pendidikan Islam : Tradisi dan modernisasi Menuju Milenium Baru Jakarta : Logos Waca ilmu, 1999.

, Pendidikan Islam : Tradisi dan modernisasi Menuju Milenium Baru (Jakarta : Logos Waca ilmu, 2002).

Djamaluddin \& Abdullah Aly, Kapita Selekta Pendidikan Islam, Bandung : Pustaka Setia, 1998.

Hasbullah, Sejarah Pendidikan Islam di Indonesia, Jakarta: PT. Raja Grafindo, 1996.

Husein Muhammad, Kontekstualisasi Kitab Kuning, dalam http://huseinmuhammad.net/kontekst ualisasi-kitab-kuning/ diakses pada tanggal 3 Desember 2015.

Imam Bawani, Tradisionalisme dalam pendidikan Islam, Surabaya : AlIkhlas, 1990. 
Irmansyah Alpandi, Didaktif Metodik Pendidikan Umum, Surabaya: Usaha Nasional, 1984.

Matushu, Dinamika Pendidikan Pesantren, Jakarta : INIS, 1994.

Nurcholis Madjid, Bilik-bilik Pesantren, Jakarta: Paramadina, 1997.

Siswanto. "Praksis Model Studi Islam dalam Komunitas Pesantren (Menuju Humanisasi Kitab Kuning)" dalam Jurnal KARSA, Jurnal Sosial dan Budaya Keislaman edisi Vol. X, No. 2, Oktober 2006, hlm. 920.

Uci Sanusi, Transfer Ilmu di Pesantren : Kajian Mengenai Sanad Ilmu, dalam Jurnal Pendidikan Islam - Ta'lim vol. 11, No. 1 Thn. 2013, hlm. 6170.

Winarno, Surahkmad, Metodologi pengajaran nasional, Jakarta: jemmars, 1979.

Yayuk Susanti, Kitab kuning dan Pesantren Menjawab tantangan Globalisasi, dalam https://garisbawahku.wordpress.com/ 2013/05/23/kitab-kuning-danpesantren-menjawab-tantanganglobalisasi/ diakses pada tanggal 14 Desember 2015.

Zamakhsyari Dhofier, Tradisi Pesantren, Jakarta: LP3ES, cet. 2. 1994. 